\title{
Effects of valproic acid on skeletal metabolism in children with epilepsy: a systematic evaluation and meta-analysis based on 14 studies
}

\author{
Li Min ${ }^{1}$, Wang Chunyan ${ }^{2}$ and Rong Biaoxue $e^{1,3^{*}}$
}

\begin{abstract}
Background: Previous studies have reported that long-term use of valproic acid can cause changes in bone metabolism in children. We conducted this meta-analysis to determine the effects of valproic acid on bone metabolism and bone mineral density (BMD) in children with epilepsy.

Methods: Studies were searched from the databases of PubMed, Embase, Ovid, Cochrance Library, Springer Link and Web of Science. The effects of valproic acid on bone metabolism indicators and BMD were assessed through calculating the standardized mean difference (SMD) with 95\% confidence interval (CI).

Results: Fourteen studies with 987 individuals were included in this analysis. The long-term use of valproic acid did not affect the levels of serum calcium $(p=0.99)$, phosphorus $(p=0.28)$, ALP $(p=0.76), \operatorname{PTH}(p=0.36)$ and osteocalcin $(p=0.72)$, but it led to a decrease in 25-OH-VitD $(p=0.01)$ and BMD $(p=0.002$ for the vertebra; $p=$ 0.004 for the femur) in treating children with epilepsy.

Conclusion: Long-term use of valproic acid in treating children with epilepsy can lead to a reduction in 25-OH-VitD and BMD. Measurements of $25-\mathrm{OH}-\mathrm{VitD}$ and BMD should be performed regularly in children taking the drug to detect early osteopenia caused by the drug.
\end{abstract}

Keywords: Valproic acid, Epilepsy; children, Bone metabolism, Bone mineral density, Meta-analysis

\section{Background}

As a chronic disorder of the brain, epilepsy affects people of all ages. Approximately 50 million people worldwide have epilepsy, making it one of the most common neurological diseases globally [1]. Epilepsy is common neurological disease in children. Although antiepileptic drugs (AEDs) do not have a "curative effect" on epilepsy, they control seizures. Valproic acid has been widely used as a long term anti epileptic medication [2], as it displays a certain effects in absence seizures, clinical depression, tonic-clonic seizures, juvenile myoclonic epilepsy and complex partial seizures [3, 4].

\footnotetext{
* Correspondence: research568rbx@yeah.net

${ }^{1}$ Nursing department, Binhe new district branch, Shenmu Hospital, Shenmu, Yulin City, Shaanxi, China

${ }^{3}$ Department of Medicine, First Affiliated Hospital, Xi'an Medical University,

Xi'an, China

Full list of author information is available at the end of the article
}

Height, weight, nutrition and cognitive status are closely related to children's growth and development, especially bone metabolism. As early as 2004, it was reported that several factors affect bone metabolism in children with epilepsy, suggesting that long-term use of AEDs may cause damage to the skeletal system [5]. Cytochrome P450 (CYP450) isozyme can be induced by AEDs such as carbamazepine, phenytoin sodium, phenobarbital and valproic acid, which may lead to vitamin D deficiency, hypocalcemia, increased fracture risk [6]. Opinions suggest that long-term use of this drug may have an impact on bone metabolism in children $[1-3,7]$. We performed a meta-analysis to determine the effects of valproic acid on bone metabolism and bone mineral density (BMD) in epileptic children.

(c) The Author(s). 2020 Open Access This article is distributed under the terms of the Creative Commons Attribution 4.0 International License (http://creativecommons.org/licenses/by/4.0/), which permits unrestricted use, distribution, and 


\section{Methods}

Literature searching

Several databases including PubMed, Embase, Ovid, Cochrance Library, Springer Link and Web of Science were searched. The key words for searching literature included: "epilepsy," "antiepileptic drugs," "valproic acid," "sodium valproate," "bone metabolism," "bone mineral density," "bone density," "children epilepsy," and "AEDs". The search strategy was to combine the topic of valproic acid with the topic of children epilepsy and to combine them with the indices of bone metabolism. We applied boolean operators, wildcards, and field identifiers to combine search terms. This meta-analysis was conducted based on the Reporting Items for Systematic Reviews and Meta-Analyses (PRISMA) statement [8].

\section{Inclusion criteria}

The inclusion criteria used were: (1) The diagnosis of children with epilepsy which met diagnostic criteria of the International Anti-Epilepsy Alliance; (2) Children were under 18 years old and could participate in outdoor activities; (3) The design type must be cohort study or case-control study; (4) The valproic acid group must be treated with valproic acid monotherapy for more than 6 months; (5) The control group must be composed of healthy children not receiving any medications; and (6)
A Potentially relevant studies identified for retrieval $(n=198)$

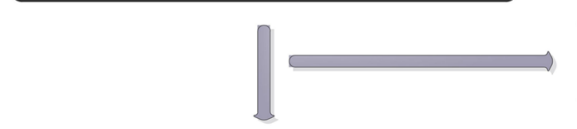

Potential studies retrieved for following detailed evaluation $(n=110)$

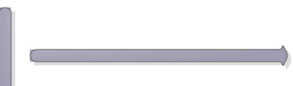

Potentially studies to be included in the systematic review $(n=39)$

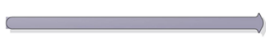

Studies that fulfilled all of the inclusion criteria $(n=14)$
Studies were not eligible for following analysis $(\mathrm{N}=88)$

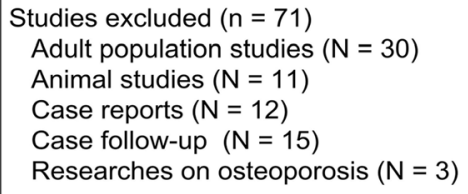

Studies excluded $(n=25)$

Complex medication $(n=13)$

Invalid outcome data $(n=9)$

Secondary epilepsy $(n=3)$

B

\begin{tabular}{|c|c|c|c|c|c|c|c|c|c|c|c|}
\hline \multicolumn{12}{|c|}{ Assessing the quality of included studies using the Newcastle-Ottawa Scale (NOS) } \\
\hline Authors & Q1 & Q2 & Q3 & Q4 & Q5 & Q6 & Q7 & Q8 & Q9 & Star & \\
\hline Akin R [11] & $\star$ & $\star$ & & $\star$ & $\star$ & $\star$ & $\star$ & $\star$ & $\star$ & 8 & \multirow{14}{*}{$\begin{array}{l}\text { Question 1: Is the case definition adequate? } \\
\text { Question 2: Representativeness of the cases } \\
\text { Question 3: Selection of Controls } \\
\text { Question 4: Definition of Controls } \\
\text { Question 5: Comparability of cases } \\
\text { Question 6: Controls on the basis of the design or analysis } \\
\text { Question 7: Ascertainment of exposure } \\
\text { Question 8: Same method of ascertainment for cases and } \\
\quad \text { controls } \\
\text { Question 9: Non-response rate }\end{array}$} \\
\hline Kafali G [17] & $\star$ & $\star$ & & $\star$ & $\star$ & $\star$ & $\star$ & $\star$ & & 7 & \\
\hline Erbayat Altay E [14] & $\star$ & $\star$ & & $\star$ & $\star \star$ & $\star$ & $\bar{\star}$ & $\star$ & $\star$ & 8 & \\
\hline Voudris K [23] & $\star$ & $\bar{\star}$ & & $\star$ & $\star$ & $\star$ & $\star$ & $\star$ & & 7 & \\
\hline Caksen H [15] & $\star$ & $\star$ & & $\star$ & $\star$ & $\star$ & $\star$ & $\star$ & $\star$ & 8 & \\
\hline Oner N [19] & $\star$ & $\star$ & & $\star$ & $\star$ & $\star$ & $\star$ & $\star$ & & 7 & \\
\hline Ecevit C [16] & $\star$ & $\star$ & & $\star$ & & $\star$ & $\star$ & $\star$ & & 6 & \\
\hline Kumandas S [18] & $\star$ & $\star$ & & $\star$ & $\star$ & $\star$ & $\star \star$ & $\star$ & $\star$ & 8 & \\
\hline Babayigit A [13] & $\star$ & $\star$ & & $\star$ & $\star$ & $\star$ & $\star$ & $\star$ & & 7 & \\
\hline Rauchenzauner M [21] & $\star$ & $\star$ & & $\star$ & & $\star$ & $\star$ & $\star$ & & 6 & \\
\hline Aksoy A [12] & $\star$ & $\star$ & & $\star$ & $\star$ & $\star$ & $\star$ & $\star$ & $\star$ & 8 & \\
\hline Yaghini O [20] & $\star$ & $\star$ & $\star$ & $\star$ & $\star$ & $\star$ & $\star$ & $\star$ & & 8 & \\
\hline Serin HM [22] & $\star$ & $\star$ & & $\star$ & $\star \star$ & $\star$ & $\star$ & $\star$ & & 7 & \\
\hline Hasaneen B [7] & $\star$ & $\star$ & $\star$ & $\star$ & & $\star$ & $\star$ & $\star$ & $\star$ & 8 & \\
\hline
\end{tabular}

Fig. 1 Flow chart of selection process and quality assessment. a After screening, 14 studies met the inclusion criteria. $\mathbf{b}$ The NOS Scale showed that these studies had a moderate to high quality. NOS, Newcastle-Ottawa Scale 
Table 1 Description of the included studies

\begin{tabular}{|c|c|c|c|c|c|c|c|c|c|c|c|c|c|c|}
\hline \multirow[t]{2}{*}{ Authors } & \multirow[t]{2}{*}{ Year } & \multicolumn{3}{|c|}{ Cases (N) } & \multicolumn{2}{|l|}{ Age (Years) } & \multicolumn{4}{|c|}{$\begin{array}{l}\text { Gender (Male/ } \\
\text { female) (N) }\end{array}$} & \multicolumn{2}{|l|}{ Weight (kg) } & \multicolumn{2}{|c|}{ Height (cm) } \\
\hline & & All & $\begin{array}{l}\text { Valproic } \\
\text { acid }\end{array}$ & control & $\begin{array}{l}\text { Valproic } \\
\text { acid }\end{array}$ & Control & $\begin{array}{l}\text { Valp } \\
\text { acid }\end{array}$ & roic & Cont & trol & $\begin{array}{l}\text { Valproic } \\
\text { acid }\end{array}$ & Control & $\begin{array}{l}\text { Valproic } \\
\text { acid }\end{array}$ & Control \\
\hline Akin R [11] & 1998 & 51 & 25 & 26 & $8.8 \pm 0.5$ & $8.9 \pm 0.6$ & 14 & 11 & 15 & 11 & $31.9 \pm 2.06$ & $29 \pm 1.8$ & $132 \pm 13.4$ & $132 \pm 3.4$ \\
\hline Kafali G [17] & 1999 & 76 & 19 & 57 & $6-12$ & $6-12$ & 10 & 9 & 29 & 28 & $28.1 \pm 8.3$ & $27.5 \pm 6.5$ & $130 \pm 10$ & $130 \pm 10$ \\
\hline $\begin{array}{l}\text { Erbayat Altay E } \\
\text { [14] }\end{array}$ & 2000 & 37 & 15 & 22 & $5.5-18$ & $7-15.5$ & 5 & 10 & 8 & 14 & $\begin{array}{l}15.5 \\
(34.67)\end{array}$ & $\begin{array}{l}20- \\
74(37.43)\end{array}$ & $\begin{array}{l}95- \\
69(135)\end{array}$ & $\begin{array}{l}112- \\
170(142.73)\end{array}$ \\
\hline Voudris K [23] & 2002 & 94 & 47 & 47 & $8.1 \pm 3.9$ & Comparable & - & - & - & - & - & - & - & - \\
\hline Caksen H [15] & 2002 & 53 & 31 & 22 & $9.0 \pm 3.1$ & $9.8 \pm 4.2$ & 17 & 14 & 12 & 10 & - & - & - & - \\
\hline Oner N [19] & 2004 & 66 & 33 & 33 & $7.1 \pm 3.5$ & $7.4 \pm 2.8$ & - & - & - & - & - & - & $121 \pm 22.2$ & $123 \pm 17.3$ \\
\hline Ecevit C [16] & 2004 & 47 & 16 & 31 & $10.6 \pm 3.2$ & $11.5 \pm 2.6$ & - & - & - & - & $\begin{array}{l}34.56 \pm \\
8.42\end{array}$ & $\begin{array}{l}40.91 \pm \\
12.44\end{array}$ & $138 \pm 12$ & $146 \pm 15$ \\
\hline Kumandas S [18] & 2006 & 55 & 33 & 22 & $8.8 \pm 2.0$ & $8.9 \pm 2.3$ & 17 & 16 & 20 & 13 & $32.8 \pm 11.9$ & $31.5 \pm 10.5$ & $\begin{array}{l}132.2 \pm \\
10.7\end{array}$ & $123 \pm 28.4$ \\
\hline Babayigit A [13] & 2006 & 61 & 31 & 30 & $11.2 \pm 4.1$ & $13.1 \pm 3.1$ & 15 & 16 & 14 & 16 & $\begin{array}{l}38.15 \pm \\
16.89\end{array}$ & $\begin{array}{l}47.98 \pm \\
15.49\end{array}$ & $143.6 \pm 22$ & $155.7 \pm 19.14$ \\
\hline $\begin{array}{l}\text { Rauchenzauner M } \\
\text { [21] }\end{array}$ & 2010 & 126 & 85 & 41 & $12.4 \pm 3.3$ & $12.1 \pm 3.5$ & 38 & 47 & 28 & 12 & - & - & - & - \\
\hline Aksoy A [12] & 2011 & 103 & 53 & 50 & $8.4 \pm 2.0$ & $8.2 \pm 1.9$ & 25 & 28 & 31 & 19 & $\begin{array}{l}27.85 \pm \\
8.49\end{array}$ & $\begin{array}{l}27.49 \pm \\
6.42\end{array}$ & $125 \pm 0.12$ & $127 \pm 0.10$ \\
\hline Yaghini O [20] & 2014 & 60 & 30 & 30 & $7.4 \pm 2.4$ & $7.9 \pm 2.4$ & - & - & - & - & - & - & - & - \\
\hline Serin HM [22] & 2015 & 48 & 28 & 20 & $8.11 \pm 3.95$ & $7.6 \pm 3.3$ & 11 & 17 & 13 & 7 & - & - & - & - \\
\hline Hasaneen B [7] & 2017 & 101 & 21 & 80 & $6.2 \pm 3.1$ & $8.7 \pm 3.4$ & 13 & 8 & 41 & 39 & - & - & - & - \\
\hline
\end{tabular}

$\mathrm{N}$, cases

Table 2 Methodology and quality of inclined studies

\begin{tabular}{lllllll}
\hline Authors & Year & Research design & Country & $\begin{array}{l}\text { Treatment } \\
\text { duration } \\
\text { /years }\end{array}$ & Serum drug level (mg/mL) & Bone metabolism index \\
\hline Akin R [1 1] & 1998 & Retrospective & Turkey & $2.4 \pm 0.2$ & $66 \pm 2.2$ & Ca, P, ALP, BMD \\
Kafali G [17] & 1999 & Retrospective & Turkey & $>0.5$ & - & ALP, BMD \\
Erbayat Altay E [14] & 2000 & Retrospective & Turkey & $3.1+1.8(1-6)$ & - & BMD \\
Voudris K [23] & 2002 & Retrospective & Greece & $>0.5$ & $59.1 \pm 2.7$ & ALP \\
Caksen H [15] & 2002 & Retrospective & Turkey & $1.93 \pm 1.90$ & $85.29 \pm 11.72$ & Ca, P, ALP, PTH, OC \\
Oner N [19] & 2004 & Retrospective & Turkey & $>0.5$ & $56.8 \pm 15.5$ & Ca, P, BMD \\
Ecevit C [16] & 2004 & Retrospective & Turkey & $>0.5$ & $53.75 \pm 23.94$ & BMD \\
Kumandas S [18] & 2006 & Retrospective & Turkey & $2.9 \pm 1.2$ & $67.37 \pm 8.31$ & Ca, P, ALP, BMD, PTH, OC, 25-OH-VitD \\
Babayigit A [13] & 2006 & Retrospective & Turkey & $>1$ & - & Ca, P, ALP, BMD, PTH, 25-OH-VitD \\
Rauchenzauner M [21] & 2010 & Retrospective & Austria & $>0.5$ & - & Ca, P, 25-OH-VitD \\
Aksoy A [12] & 2011 & Retrospective & Turkey & $3.23 \pm 1.09$ & $56.96 \pm 7.34$ & Ca, P, ALP, BMD, OC, 25-OH-VitD \\
Yaghini O [20] & 2014 & Retrospective & Iran & $>0.5$ & - & Ca, P, ALP, BMD, PTH \\
Serin HM [22] & 2015 & Retrospective & Turkey & $>0.5$ & - & Ca, P, ALP, BMD, PTH \\
Hasaneen B [7] & 2017 & Retrospective & Egypt & $1.3 \pm 0.6$ & - & Ca, P, BMD, PTH
\end{tabular}


The study must have at least one of the following study endpoints: serum calcium, phosphorus, alkaline phosphatase (ALP), parathyroid hormone (PTH), osteocalcin, and 25-hydroxy-vitamin D (25-OH-VitD) and bone mineral density (BMD).

\section{Exclusion criteria}

The exclusion criteria used were: (1) Studies that contained children with encephalitis and other secondary epilepsy; (2) Lack of clear grouping (valproic acid group and healthy children group); (3) Children with epilepsy receiving other treatments; (4) Research costs were provided by drug manufacturers or studies initiated by drug producers; (5) The time of administration of valproic acid was not indicated, or the continuous medication was shorter than 6 months.

\section{Extraction of study variables}

The extracted data included: (1) Author's name, date of publication, and region of the research; (2) Study design and case number of different groups; (3) General demographic characteristics and baseline conditions; (4) The duration and average blood concentration of valproic acid; and (5) Bone metabolism indicators: calcium, serum phosphorus, ALP, PTH, osteocalcin, 25-OH-VitD and BMD.

\section{Methodological quality assessment}

The quality of studies was evaluated using the Newcastle-Ottawa Scale (NOS) [9]. Each study was judged on eight items, categorized into three groups: the selection of the study groups; the comparability of the groups; and the ascertainment of either the exposure or outcome of interest for case-control or cohort studies respectively. A qualified project was awarded a star and the highest quality research will be awarded 9 stars $[9$, 10]. The two authors performed the evaluation independently. If there was disagreement, a third expert was invited to discuss and reach a consensus.

Table 3 The effect of valproic acid on bone metabolism in epileptic children

\begin{tabular}{|c|c|c|c|c|c|c|c|c|c|c|c|c|}
\hline \multirow[t]{3}{*}{ Author } & \multicolumn{12}{|c|}{ Bone metabolism index (Mean \pm standard deviation) } \\
\hline & \multicolumn{2}{|c|}{$\begin{array}{l}\text { Serum calcium } \\
(\mathrm{mg} / \mathrm{dL})\end{array}$} & \multicolumn{2}{|c|}{$\begin{array}{l}\text { Serum } \\
\text { phosphorus (mg/ } \\
\mathrm{dL} \text { ) }\end{array}$} & \multicolumn{2}{|c|}{$\begin{array}{l}\text { Alkaline phosphatase } \\
(\mathrm{U} / \mathrm{L})\end{array}$} & \multicolumn{2}{|c|}{$\begin{array}{l}\text { Parathyroid } \\
\text { hormone (pg/mL) }\end{array}$} & \multicolumn{2}{|c|}{$\begin{array}{l}\text { Osteocalcin } \\
\text { (Inconsistent) }^{\text {d }}\end{array}$} & \multicolumn{2}{|c|}{$\begin{array}{l}\text { 25-hydroxy-vitamin } \\
\text { D (ng/ml) }\end{array}$} \\
\hline & $\begin{array}{l}\text { Valproic } \\
\text { acid }\end{array}$ & Control & $\begin{array}{l}\text { Valproic } \\
\text { acid }\end{array}$ & Control & $\begin{array}{l}\text { Valproic } \\
\text { acid }\end{array}$ & Control & $\begin{array}{l}\text { Valproic } \\
\text { acid }\end{array}$ & Control & $\begin{array}{l}\text { Valproic } \\
\text { acid }\end{array}$ & Control & $\begin{array}{l}\text { Valproic } \\
\text { acid }\end{array}$ & Control \\
\hline Akin R [11] & $\begin{array}{l}9.08 \pm \\
0.1\end{array}$ & $\begin{array}{l}9.42 \pm \\
0.1\end{array}$ & $\begin{array}{l}5.39 \pm \\
0.2\end{array}$ & $\begin{array}{l}5.24 \pm \\
0.2\end{array}$ & $194 \pm 18^{c}$ & $204 \pm 11^{c}$ & - & - & - & - & - & - \\
\hline Kafali G [17] & - & - & - & - & $\begin{array}{l}569.35 \pm \\
263.35\end{array}$ & $\begin{array}{l}303.7 \pm \\
109.8\end{array}$ & - & - & - & & - & - \\
\hline $\begin{array}{l}\text { Erbayat Altay E } \\
{[14]}\end{array}$ & - & - & - & - & - & - & - & - & - & - & - & - \\
\hline Voudris K [23] & - & - & - & - & $\begin{array}{l}162.3 \pm \\
71.8\end{array}$ & $\begin{array}{l}144.9 \pm \\
53.3\end{array}$ & - & - & - & - & - & - \\
\hline Caksen H [15] & $\begin{array}{l}9.84 \pm \\
0.62\end{array}$ & $\begin{array}{l}9.80 \pm \\
0.39\end{array}$ & $\begin{array}{l}5.02 \pm \\
0.72\end{array}$ & $\begin{array}{l}5.10 \pm \\
0.58\end{array}$ & $\begin{array}{l}481.51 \pm \\
165.56\end{array}$ & $\begin{array}{l}554.77 \pm \\
210.41\end{array}$ & $\begin{array}{l}35.38 \pm \\
31.06\end{array}$ & $\begin{array}{l}33.14 \pm \\
17.18\end{array}$ & $\begin{array}{l}3.13 \pm \\
3.22\end{array}$ & $\begin{array}{l}3.11 \pm \\
2.43\end{array}$ & - & - \\
\hline Oner N [19] & $\begin{array}{l}10.02 \pm \\
0.4^{a}\end{array}$ & $\begin{array}{l}10.42 \pm \\
0.4^{a}\end{array}$ & $\begin{array}{l}4.87 \pm \\
0.8\end{array}$ & $\begin{array}{l}5.1 \pm \\
1.1\end{array}$ & - & - & - & - & $\begin{array}{l}276.3 \pm \\
136.6\end{array}$ & $\begin{array}{l}201.4 \pm \\
82.9\end{array}$ & - & - \\
\hline $\begin{array}{l}\text { Kumandas S } \\
\text { [18] }\end{array}$ & $9.9 \pm 0.3$ & $\begin{array}{l}9.7 \pm \\
0.4\end{array}$ & $4.4 \pm 0.5$ & $\begin{array}{l}4.5 \pm \\
0.4\end{array}$ & $561 \pm 166$ & $487 \pm 82$ & $\begin{array}{l}39.1 \pm \\
12.8\end{array}$ & $\begin{array}{l}36.3 \pm \\
4.9\end{array}$ & - & - & $\begin{array}{l}15.1 \pm \\
3.5^{\mathrm{e}}\end{array}$ & $\begin{array}{l}16.6 \pm \\
4.7^{e}\end{array}$ \\
\hline Babayigit A [13] & $\begin{array}{l}9.95 \pm \\
0.41\end{array}$ & $\begin{array}{l}9.89 \pm \\
0.35\end{array}$ & $\begin{array}{l}3.53 \pm \\
0.57\end{array}$ & $\begin{array}{l}3.49 \pm \\
0.47\end{array}$ & $\begin{array}{l}506.3 \pm \\
215.1\end{array}$ & $\begin{array}{l}436.5 \pm \\
147.9\end{array}$ & $\begin{array}{l}43.46 \pm \\
22.1\end{array}$ & $\begin{array}{l}38.17 \pm \\
14.8\end{array}$ & - & - & $\begin{array}{l}17.87 \pm \\
7.27\end{array}$ & $\begin{array}{l}22.3 \pm \\
7.1\end{array}$ \\
\hline $\begin{array}{l}\text { Rauchenzauner } \\
\text { M [21] }\end{array}$ & $\begin{array}{l}9.89 \pm \\
0.32^{\mathrm{a}}\end{array}$ & $\begin{array}{l}9.37 \pm \\
0.3^{a}\end{array}$ & $\begin{array}{l}4.2 \pm \\
0.6^{b}\end{array}$ & $\begin{array}{l}4.5 \pm \\
0.6^{\mathrm{b}}\end{array}$ & - & - & - & - & - & - & $\begin{array}{l}43.2 \pm \\
25.6\end{array}$ & $\begin{array}{l}49.9 \pm \\
33.8\end{array}$ \\
\hline Aksoy A [12] & $\begin{array}{l}9.84 \pm \\
0.38\end{array}$ & $\begin{array}{l}9.93 \pm \\
0.45\end{array}$ & $\begin{array}{l}4.87 \pm \\
0.44\end{array}$ & $\begin{array}{l}4.90 \pm \\
0.44\end{array}$ & $\begin{array}{l}422.74 \pm \\
177.52\end{array}$ & $\begin{array}{l}518.34 \pm \\
158.82\end{array}$ & - & - & $\begin{array}{l}100.27 \pm \\
34.09\end{array}$ & $\begin{array}{l}120.93 \pm \\
41.57\end{array}$ & $\begin{array}{l}37.68 \pm \\
30.73\end{array}$ & $\begin{array}{l}38.82 \pm \\
27.33\end{array}$ \\
\hline Yaghini O [20] & $\begin{array}{l}9.67 \pm \\
0.37\end{array}$ & $\begin{array}{l}9.58 \pm \\
0.46\end{array}$ & $\begin{array}{l}4.78 \pm \\
0.75\end{array}$ & $\begin{array}{l}4.84 \pm \\
0.36\end{array}$ & $\begin{array}{l}204.10 \pm \\
58\end{array}$ & $\begin{array}{l}270.13 \pm \\
106\end{array}$ & $\begin{array}{l}54.82 \pm \\
16.33\end{array}$ & $\begin{array}{l}80.09 \pm \\
49.35\end{array}$ & - & - & - & - \\
\hline Serin HM [22] & $\begin{array}{l}9.42 \pm \\
0.44\end{array}$ & $\begin{array}{l}9.5 \pm \\
0.2\end{array}$ & $4.9 \pm 0.5$ & $\begin{array}{l}4.8 \pm \\
0.8\end{array}$ & $\begin{array}{l}202.36 \pm \\
65.87\end{array}$ & $\begin{array}{l}183.7 \pm \\
50.9\end{array}$ & $\begin{array}{l}44.29 \pm \\
20.04\end{array}$ & $35.1 \pm 13$ & - & - & - & - \\
\hline Hasaneen B [7] & $7.9 \pm 1.2$ & $\begin{array}{l}8.6 \pm \\
1.2\end{array}$ & $4.5 \pm 0.8$ & $\begin{array}{l}5.3 \pm \\
0.7\end{array}$ & - & - & $\begin{array}{l}38.1 \pm \\
27.2\end{array}$ & $\begin{array}{l}29.6 \pm \\
7.4\end{array}$ & - & - & - & - \\
\hline
\end{tabular}

${ }^{a}$ Data has been converted, $\mathrm{Ca}^{2+}: \mathrm{mmol} / \mathrm{L} \times 4.008=\mathrm{mg} / \mathrm{dL}^{\circ}{ }^{\mathrm{b}}$ Data has been converted, $\mathrm{P}: \mathrm{mmol} / \mathrm{L} \times 3.097=\mathrm{mg} / \mathrm{dL} ;{ }^{\mathrm{c}}$ Data has been converted, $\mathrm{mU} / \mathrm{ml} \times 1000 /$ $1000=\mathrm{U} / \mathrm{L} ;{ }^{\mathrm{d}}$ Different detection methods cannot be used to achieve unity; ${ }^{\mathrm{e}}$ Data has been converted, ug/L $\times 1000 / 1000=\mathrm{ng} / \mathrm{ml}$ 


\section{Statistical analysis}

The statistical methods involved in this study: (1) Chisquare test and $\mathrm{I}^{2}$ statistical test were used to assess the heterogeneity of included studies. If the $p$-value of the chi-square test was greater than 0.10 , and the value of $\mathrm{I}^{2}$ was less than or equal to $50 \%$, indicating low risk of heterogeneity, we choose the fixed-effect method of metaanalysis. Otherwise, we used a random effects model; (2) The standard mean difference (SMD) and 95\% confidence interval $(\mathrm{CI})$ were used to estimate the statistical effect; (3) The overall effect of the meta-analysis was tested using Z-scores with a significance of being set at $p<0.05$; (4) Each study was removed from the estimated pool and analyzed to determine whether the addition and withdrawal of any study affected the overall statistical effect; (5) A funnel plot analysis, Begg's test and Egger's test were performed to evaluate the reliability of publication biases; (6) The SPSS (version 19.0, Chicago, USA) software was used to complete general statistics of measurement data; (7) Two computer software programs, Revman 5.2 (Cochrane collaboration) and Stata 14.0 (Stata Corporation, TX, USA), were used to perform the meta analysis of measurement data.

\section{Results}

A total of 14 studies were included in this meta-analysis Of the initial 198 studies, 88 did not meet inclusion criteria (reviews, summary of meetings and non-human studies). Of the remaining 110, 71 were excluded (adult population studies, animal research, case reports, lost to follow-up and

Study Comparison of serum calcium and phosphorus between

ID valproic acid group and healthy control group

\section{$\%$}

$\operatorname{SMD}(95 \% \mathrm{Cl}) \quad$ Weight
A 1 Serum calcium

Akin R [11] (1998)

Caksen H [15] (2002)

Oner N [19] (2004)

Kumandas S [18] (2006)

Babayigit A [13] (2006)

Rauchenzauner M [21] (2010)

Aksoy A [12] (2011)

Yaghini O [20] (2014)

Serin HM [22] (2015)

Hasaneen B [7] (2017)

Subtotal (I-squared $=90.2 \%, p=0.000$ )

B 2 Serum phosphorus

Akin R [11] (1998)

Caksen H [15] (2002)

Oner N [19] (2004)

Kumandas S [18] (2006)

Babayigit A [13] (2006)

Rauchenzauner M [21] (2010)

Aksoy A [12] (2011)

Yaghini O [20] (2014)

Serin HM [22] (2015)

Hasaneen B [7] (2017)

Subtotal $(I-$ squared $=68.8 \%, p=0.001)$

NOTE: Weights are from random effects analysis $-5$

$\begin{array}{cc}-0.75(-1.32,-0.18) & 4.79 \\ 0.07(-0.47,0.62) & 4.87 \\ -1.00(-1.51,-0.49) & 4.97 \\ 0.58(0.03,1.13) & 4.85 \\ 0.16(-0.35,0.66) & 5.01 \\ 1.66(1.23,2.08) & 5.24 \\ -0.22(-0.60,0.17) & 5.35 \\ 0.22(-0.29,0.72) & 4.99 \\ -0.22(-0.80,0.35) & 4.77 \\ -0.58(-1.07,-0.10) & 5.05 \\ -0.00(-0.51,0.50) & 49.89\end{array}$

$0.75(0.18,1.32)$

$-0.12(-0.67,0.43)$

$-0.24(-0.72,0.25)$

$-0.22(-0.76,0.33)$

$0.08(-0.43,0.58)$

$-0.50(-0.88,-0.12)$

$-0.07(-0.45,0.32)$

$-0.10(-0.61,0.40)$

$0.16(-0.42,0.73)$

$-1.11(-1.61,-0.60)$

$-0.15(-0.43,0.13)$

4.79

4.86

5.06

4.88

5.01

5.38

5.35

4.99

4.77

5.00

$z=1.07$

$p=0.28$

Fig. 2 Comparison of serum calcium and phosphorus between valproic acid group and healthy control group. a and $\mathbf{b}$ There was no significant difference in serum calcium and phosphorus between valproic acid group and control group. Cl, confidence interval 
reports on osteoporosis). Of the remaining 39, 25 were excluded (complicated treatment, invalid outcome and research on secondary epilepsy) (Fig. 1a). Finally, a total of 14 [11-23] were recruited in this meta-analysis (Table 1).

\section{Included studies show good homogeneity and comparability}

Fourteen studies [11-23] published between 1998 and 2017 with a total 978 children were included in this meta-analysis (Table 1). Studies ranged in size from 37 [14] - 126 cases [21] with 467 in the valproate group and 511 cases in the control group. Boys accounted for $48.4 \%$ in the valproic acid group and $55.5 \%$ in control group $(p>0.05)$. Seven studies showed data on height and weight $[11-14,16-18]$ with no statistical differences between the valproic acid group and the control group $(p>0.05)$.
Included studies show moderate to high research quality Fourteen studies [11-23] were retrospective singlecenter studies. Ten studies [11-19, 22] originated from Turkey, and the other four studies from Greece [23], Austria [21], Iran [20] and Egypt [7] (Table 2). Six studies $[7,11,12,14,15,18]$ provided high quality research data. Seven studies [11, 12, 15, 16, 18, 19, 23] reported serum level of valproic acid. Eleven studies [11-15, 17$20,22,23]$ showed a low risk of selection bias. In summary, seven studies $[7,11,12,14,15,18,20]$ received eight stars, five $[13,17,19,22,23]$ received seven and two $[16,21]$ were six (Fig. 1b).

Valproic acid does not affect the levels of serum calcium and phosphorus in children with epilepsy

Ten studies [7, 11-13, 15, 18-22] compared the level of serum calcium between valproic acid group and healthy
Study Comparison of serum alkaline phosphatase and parathyroid hormone ID

\section{between valproic acid group and healthy control group}

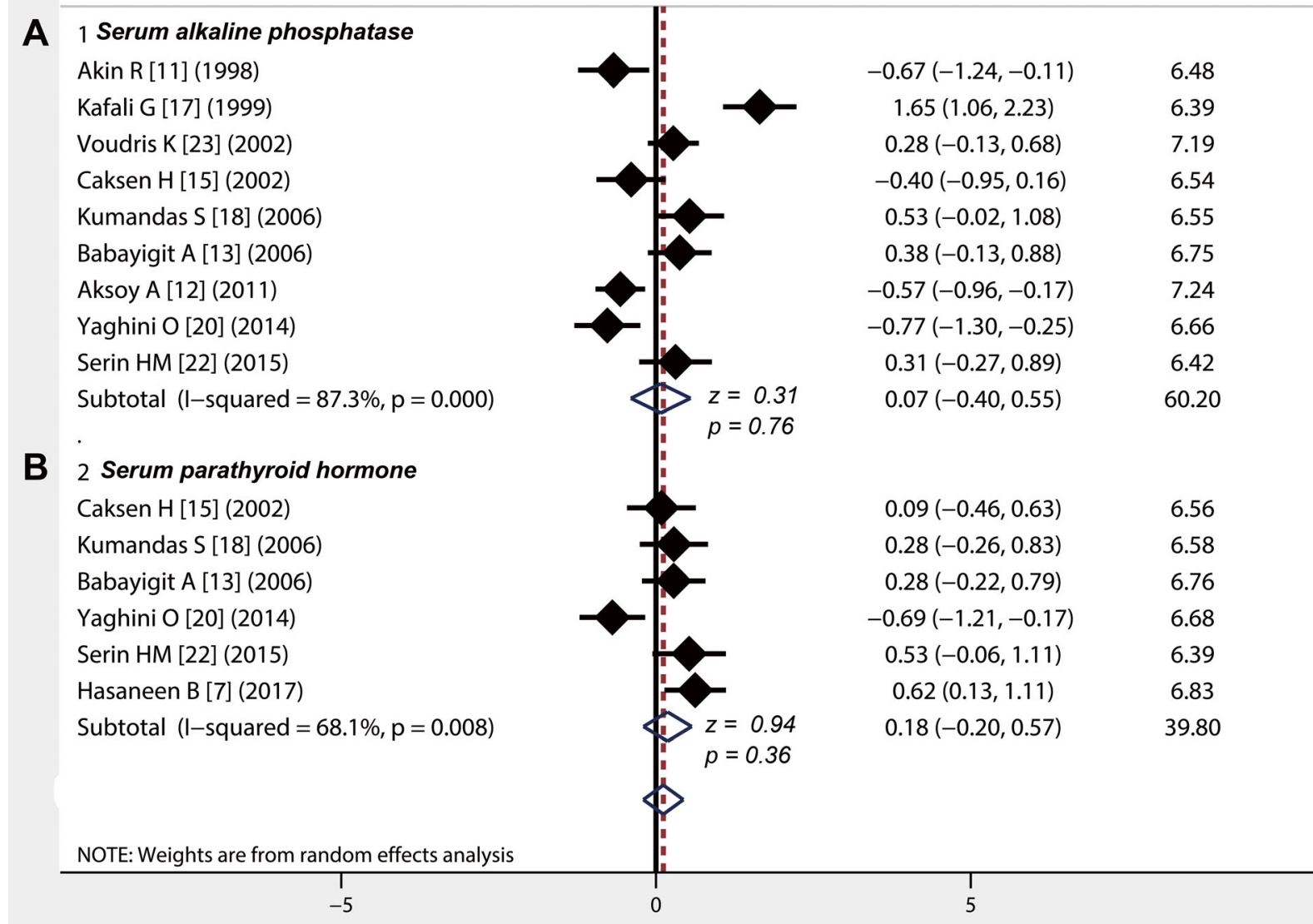

Fig. 3 Comparison of serum alkaline phosphatase and parathyroid hormone between valproic acid group and healthy control group. $\mathbf{a}$ and $\mathbf{b}$ Valproic acid did not affect the levels of serum alkaline phosphatase and parathyroid hormone in children with epilepsy. Cl, confidence interval 
control group and showed a chi-square value of 91.77 (degrees of freedom $=9 ; p<0.001$ ) and $I$-square value of $90.2 \%$ (Table 3). The weight of included studies ranged from 4.77 to $5.35 \%$, and the pooled SMD was -0.00 ( $95 \%$ CI: -0.51 to -0.50 ) (Fig. 2a), showing that valproic acid did not affect the level of serum calcium in children with epilepsy $(\mathrm{z}=0.01, P=0.99)$. Ten studies $[7,11-13$, 15, 18-22] compared the serum phosphorus level and showed a chi-square statistic of 28.89 (degrees of freedom $=9 ; p=0.001$ ) and $I$-square of $68.8 \%$ (Table 3 ). The combined SMD was -0.15 (95\% CI: -0.43 to 0.13 ), suggesting that valproic acid did not affect the level of serum phosphorus in children with epilepsy $(\mathrm{z}=1.07$, $P=0.28)$ (Fig. 2b).

Levels of serum ALP and PTH in children with epilepsy are not affected by the long-term use of valproic acid To compare the levels of serum ALP and PTH, the chisquare values were 62.9 and $15.69(p=0.008$ and $p<$ 0.001 ) and the $I$-square values were 87.3 and $68.1 \%$.
Nine studies [11-13, 15, 17, 18, 20, 22, 23] compared the level of serum ALP between valproic acid group and control group (Table 3). The combined SMD was 0.07 and the $95 \% \mathrm{CI}$ was -0.40 to 0.55 , showing that valproic acid did not affect the level of serum ALP in children with epilepsy ( $\mathrm{z}=0.31, P=0.76$ ) (Fig. 3a). Six studies [7, $13,15,18,20,22]$ compared the serum level of PTH (Table 3) and the combined SMD was 0.18 (95\% CI: 0.20 to $0.43 ; \mathrm{z}=0.94, P=0.36$ ), showing that valproic acid did not affect the level of serum PTH in children with epilepsy (Fig. 3b).

Level of serum osteocalcin in children with epilepsy is not affected by the long-term use of valproic acid

To compare the levels of serum osteocalcin, the chisquare value was $43.21(p<0.001)$ and the $I$-square values was $94.1 \%$. Three studies $[12,15,19]$ compared the serum osteocalcin level between valproic acid group and control group (Table 3). The combined SMD was 0.22 (95\% CI: -1.43 to $0.98 ; \mathrm{z}=0.36, P=0.72$ ), which

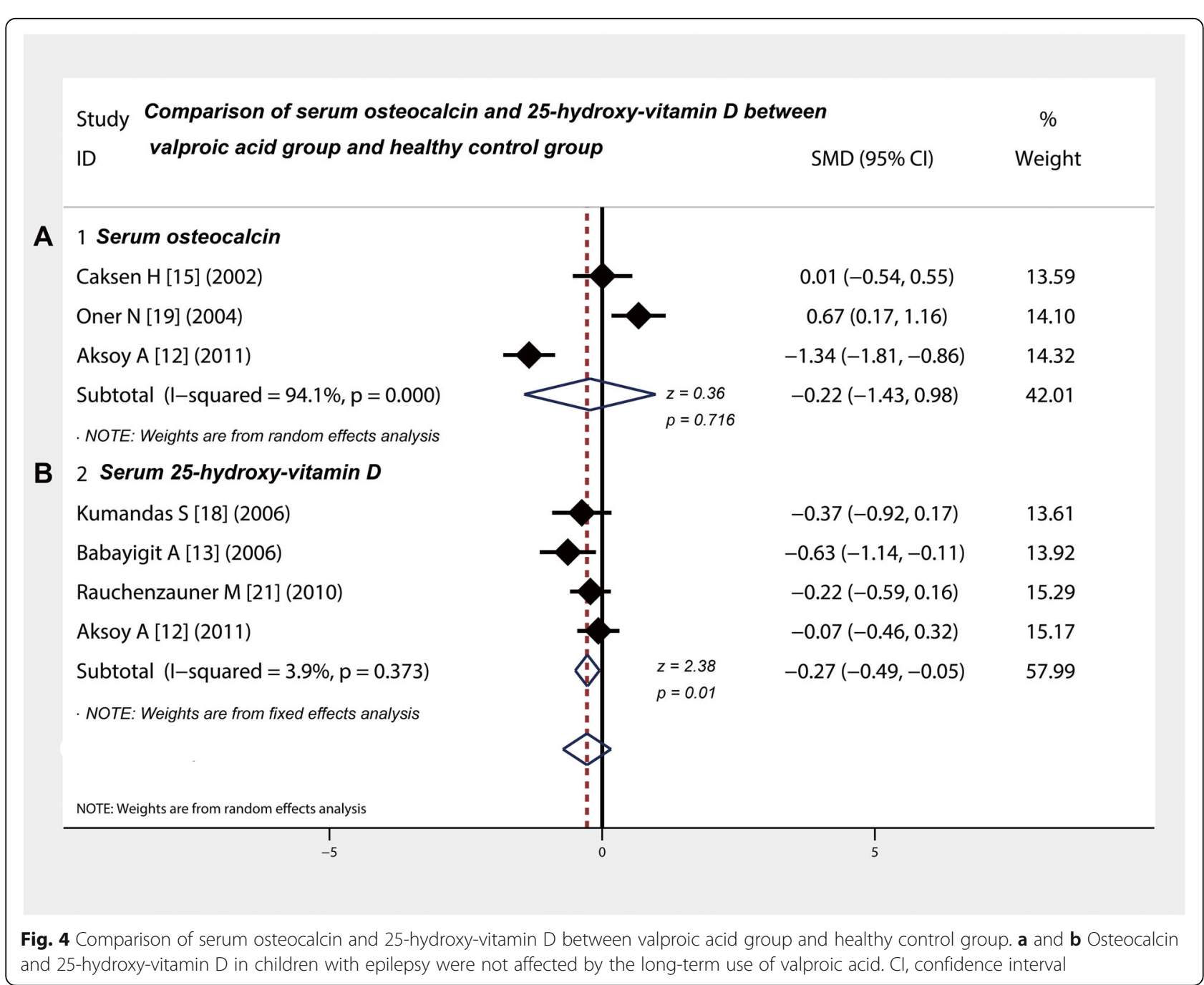


Table 4 The effect of valproic acid on bone mineral density in epileptic children

\begin{tabular}{|c|c|c|c|c|c|c|c|c|c|}
\hline \multirow[t]{3}{*}{ Author } & \multirow[t]{3}{*}{ Year } & \multirow[t]{3}{*}{ Testing method } & \multirow[t]{3}{*}{ Testing Equipment } & \multicolumn{6}{|c|}{ Bone mineral density (Mean \pm standard deviation) } \\
\hline & & & & \multicolumn{2}{|c|}{ Cases (N) } & \multicolumn{2}{|c|}{ Vertebral $\left(\mathrm{gm} / \mathrm{cm}^{2}\right)$} & \multicolumn{2}{|c|}{ Femur $\left(\mathrm{gm} / \mathrm{cm}^{2}\right)$} \\
\hline & & & & $\begin{array}{l}\text { Valproic } \\
\text { acid }\end{array}$ & Control & $\begin{array}{l}\text { Valproic } \\
\text { acid }\end{array}$ & Control & $\begin{array}{l}\text { Valproic } \\
\text { acid }\end{array}$ & Control \\
\hline Akin R [11] & 1998 & DXA & $\begin{array}{l}\text { DXA Norland (Fort Atkinson, WI) XR-36 } \\
\text { densitometer }\end{array}$ & 25 & 26 & $\begin{array}{l}0.574 \pm \\
0.02\end{array}$ & $\begin{array}{l}0.568 \pm \\
0.02\end{array}$ & - & - \\
\hline Kafali G [17] & 1999 & DXA & DEXA, QDR 4500 W Acclaim,Hologic & 19 & 57 & $\begin{array}{l}0.517 \pm \\
0.07\end{array}$ & $\begin{array}{l}0.548 \pm \\
0.07\end{array}$ & - & - \\
\hline $\begin{array}{l}\text { Erbayat Altay } \\
\text { E [14] }\end{array}$ & 2000 & DXA & $\begin{array}{l}\text { DXA Norland (Fort Atkinson, WI) XR-36 } \\
\text { densitometer }\end{array}$ & 15 & 22 & $\begin{array}{l}0.596 \pm \\
0.09\end{array}$ & $\begin{array}{l}0.624 \pm \\
0.08\end{array}$ & $\begin{array}{l}0.66 \pm \\
0.08\end{array}$ & $\begin{array}{l}0.72 \pm \\
0.07\end{array}$ \\
\hline Oner N [19] & 2004 & DEXA & $\begin{array}{l}\text { Norland XR-36 analyzer, Norland Med- } \\
\text { ical System, USA }\end{array}$ & 33 & 33 & $\begin{array}{l}0.56 \pm \\
0.2\end{array}$ & $\begin{array}{l}0.57 \pm \\
0.1\end{array}$ & $\begin{array}{l}0.61 \pm \\
0.2\end{array}$ & $\begin{array}{l}0.69 \pm \\
0.1\end{array}$ \\
\hline Ecevit C [16] & 2004 & DXA & $\begin{array}{l}\text { XR-36, Norland, Hologic (Medical } \\
\text { Equipment Company, Minster, OH) }\end{array}$ & 16 & 31 & - & - & $\begin{array}{l}0.67 \pm \\
0.08\end{array}$ & $\begin{array}{l}0.73 \pm \\
0.1\end{array}$ \\
\hline $\begin{array}{l}\text { Kumandas S } \\
{[18]}\end{array}$ & 2006 & DEXA & Hologic QDR 4500 Elite DEXA (USA) & 33 & 22 & $\begin{array}{l}0.60 \pm \\
0.09\end{array}$ & $\begin{array}{l}0.65 \pm \\
0.09\end{array}$ & - & - \\
\hline $\begin{array}{l}\text { Babayigit A } \\
\text { [13] }\end{array}$ & 2006 & DXA & $\begin{array}{l}\text { Hologic QDR } 4500 \text { W bone } \\
\text { densitometer }\end{array}$ & 31 & 30 & $\begin{array}{l}0.665 \pm \\
0.20\end{array}$ & $\begin{array}{l}0.807 \pm \\
0.13\end{array}$ & - & - \\
\hline Aksoy A [12] & 2011 & DXA & $\begin{array}{l}\text { QDR-2000/W densitometer (Hologic, } \\
\text { Waltham, MA, USA) }\end{array}$ & 53 & 50 & $\begin{array}{l}0.58 \pm \\
0.08\end{array}$ & $\begin{array}{l}0.61 \pm \\
0.08\end{array}$ & - & - \\
\hline Serin HM [22] & 2015 & DXA & Discovery Xi, Hologic & 28 & 20 & $\begin{array}{l}0.58 \pm \\
0.13\end{array}$ & $\begin{array}{l}0.53 \pm \\
0.13\end{array}$ & $\begin{array}{l}0.6 \pm \\
0.13\end{array}$ & $\begin{array}{l}0.58 \pm \\
0.13\end{array}$ \\
\hline $\begin{array}{l}\text { Hasaneen B } \\
\text { [7] }\end{array}$ & 2017 & $\begin{array}{l}\text { Dual photon X-ray } \\
\text { absorptiometry }\end{array}$ & DXA; Lunar DPX IQ-USA & 21 & 80 & $\begin{array}{l}0.63 \pm \\
0.17\end{array}$ & $\begin{array}{l}0.68 \pm \\
0.17\end{array}$ & - & - \\
\hline
\end{tabular}

DXA Dual-energy $\mathrm{x}$-ray absorptiometry, DEXA Dual-energy X-ray absorptiometry

suggested that the level of serum osteocalcin in children with epilepsy was not affected by the long-term use of valproic acid (Fig. 4a).

\section{Long-term use of valproic acid leads to a decline of serum $25-\mathrm{OH}-\mathrm{VitD}$ level in epilepsy children}

To compare the level of 25-OH-VitD, the chi-square value was $3.12(p=0.373)$ and the $I$-square value of $3.9 \%$. Four studies $[12,13,18,21]$ compared the level of $25-\mathrm{OH}-\mathrm{VitD}$ between in the valproic acid group and healthy control group (Table 3). The pooled SMD was 0.27 ( $95 \% \mathrm{CI}:-0.49$ to -0.05 ) (Fig. $4 \mathrm{~b}$ ), suggesting that the level of $25-\mathrm{OH}-\mathrm{VitD}$ in valproic acid group was significantly lower than that in control group $(\mathrm{z}=2.38, P=$ $0.01)$.

\section{Long-term use of valproic acid reduces the BMD in children with epilepsy}

The heterogeneity test on BMD of lumbar vertebrae and femur in 9 studies [7, 11-14, 17-19, 22] did not show statistical significance $(p=0.051$ and 0.018$)$. The BMD of lumbar vertebrae in valproic acid group and control group were measured in 9 studies [7, 11-14, 17-19, 22] (Table 4) and showed that the BMD of vertebral in valproic acid group was significantly lower than that in the control group $(\mathrm{SMD}=-0.27,95 \% \mathrm{CI}:-0.44$ to -0.10 , $P=0.002$ ) (Fig. 5a). Four studies $[14,16,19,22]$ compared the BMD of the femur (Table 4). The pooled
SMD was -0.42 (95\% CI: -0.71 to -0.13 ) (Fig. 5b), indicating that the BMD of the femur in valproic acid group was significantly lower than that in control group $(\mathrm{z}=2.86, P=0.004)$.

\section{Analysis of sensitivity and publication bias}

Sensitivity analysis suggested that the exclusion of any study did not substantially alter the estimates and affect the final statistical analysis. The SMD pool oscillated between -1.11 and 0.75 (Fig. 6a). The Egger's test showed that the $T$ value was $-1.26(\operatorname{Pr}>|t|=0.313)$ and the Begg's Test showed that the Std. Dev. of Score was 11.18 $(\operatorname{Pr}>|z|=0.152)$. The discrete graph produced by Egger's test indicated that included studies were basically distributed on both sides of the estimated line (Fig. 6b). The funnel plot produced by Begg's Test showed that the included studies were symmetrically distributed on both sides of the bottom of the funnel plot (Fig. 6c). Based on the above evidence, there is a very small probability of publication bias in these studies.

\section{Discussion}

In addition to the influence of nutritional status, the metabolism of the skeletal system in children is also affected by multiple factors such as chronic disease, drugs, and outdoor exercise time [24, 25]. Valproic acid has been used as one of the traditional agents to control epileptic seizures in children [2, 13]. As early as 2003, one 


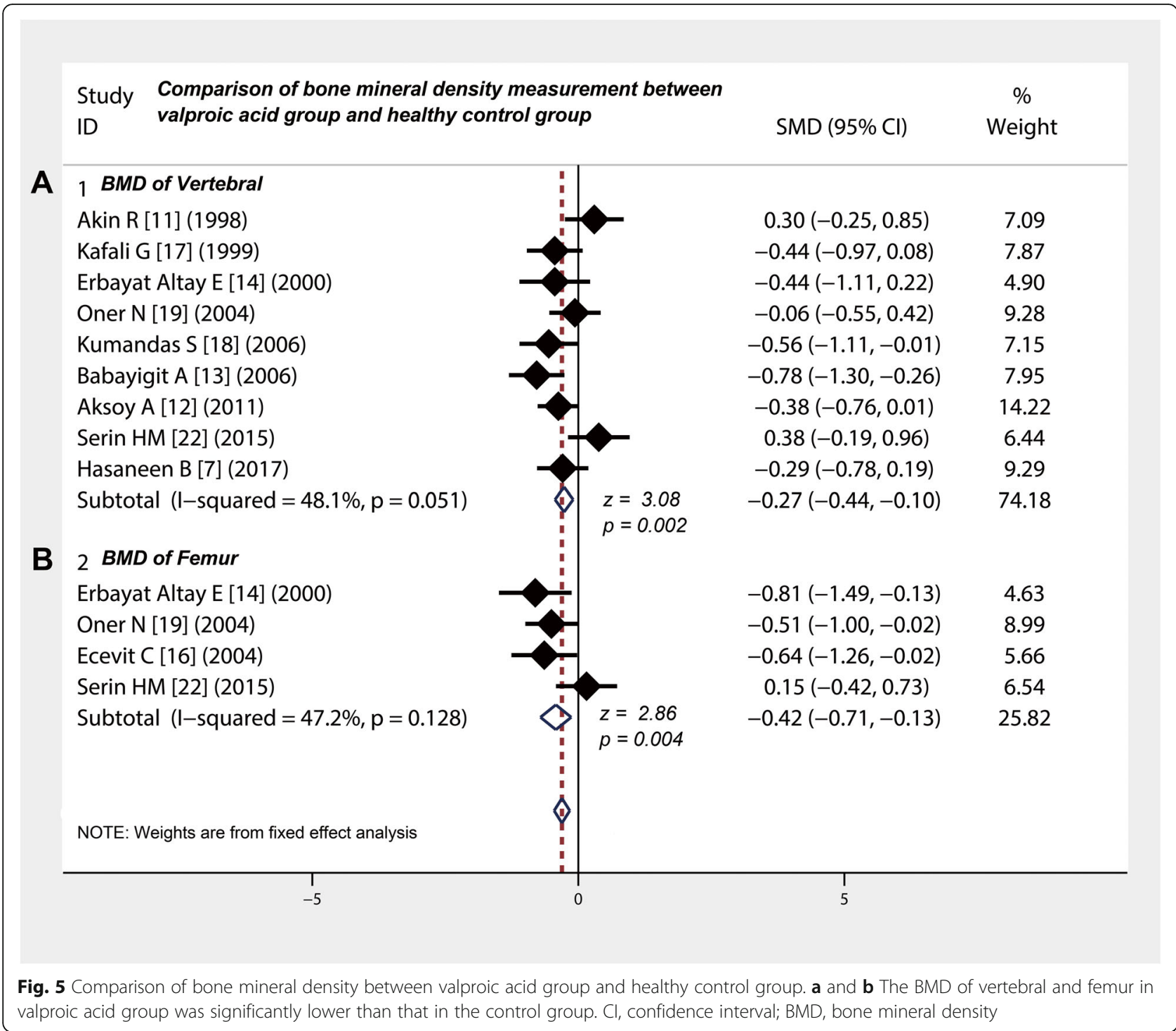

study proposed that the long-term use of AEDs may cause damage to the skeletal system [19], and was followed by several multi disciplinary research studies on this topic [7, 12-15, 18-20, 23]. As a liver enzyme inhibitor, valproic acid has been reported to affect bone metabolism, but results are inconsistent [11-23]. We collected observational studies on children with epilepsy receiving valproic acid to assess the potential effects of this medication on bone metabolism.

A total of 14 studies [11-23] were included in our analysis. We found that the long-term use of valproic acid did not affect the levels of blood calcium, phosphorus, ALP, PTH and osteocalcin in epileptic children [26]. Our study showed that the level of 25-OH-VitD in valproic acid group was significantly lower than that of the healthy control group, which implies that valproic acid may affect bone metabolism by downregulating the level of 25-OH-VitD. Through the action of liver 25hydroxylase, human exogenous and endogenous Vitmin D2 and D3 are converted into 25-OH-VitD, which requires the action of 1- $\alpha$ hydroxylase in the proximal tubule of the kidney to form active 1-25-OH-VitD [27]. Previous studies suggest that both valproic acid and its intermediate metabolite 4-ene-VPA can be hepatotoxic, especially to mitochondrial function, which can affect the hydroxylation function of liver and kidney through inhibiting the activity of P450 isozyme CYP2C191 and uridine diphosphate transferase, thus further affect the synthesis of 1, 25-OH-VitD [28, 29].

Dual-energy $\mathrm{x}$-ray absorptiometry (DEXA) has been recommended to measure the BMD of children [30]. Fourteen studies included in our meta-analysis all used DEXA as a measure of BMD, and results indicated that there was very good homogeneity and comparability between these 
A

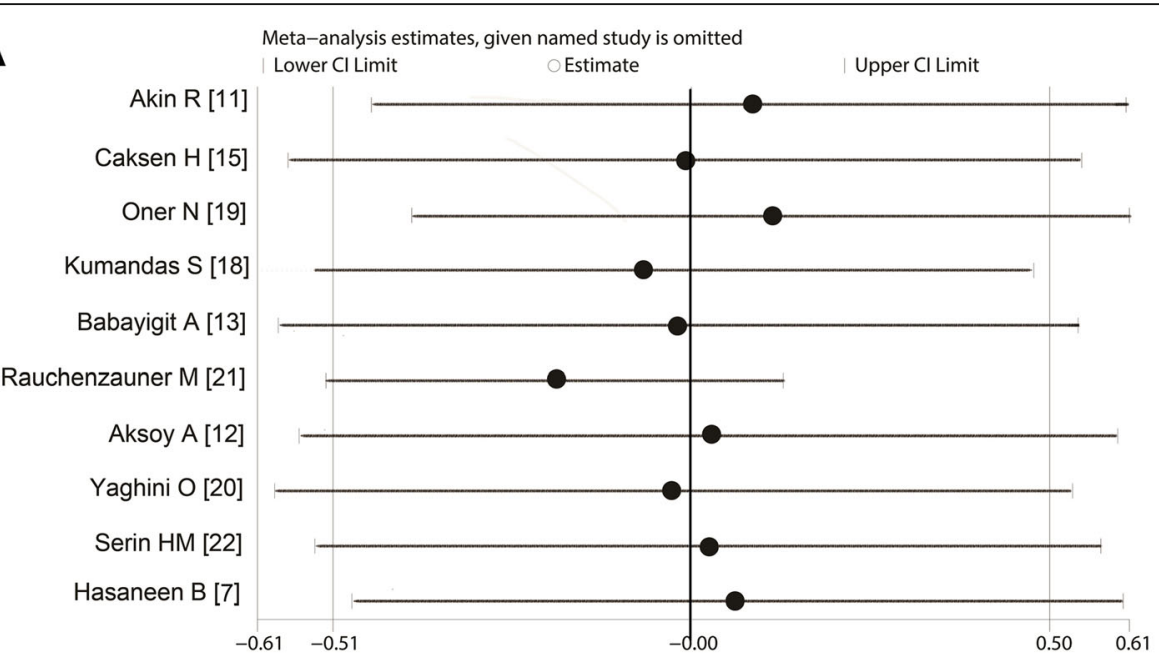

B

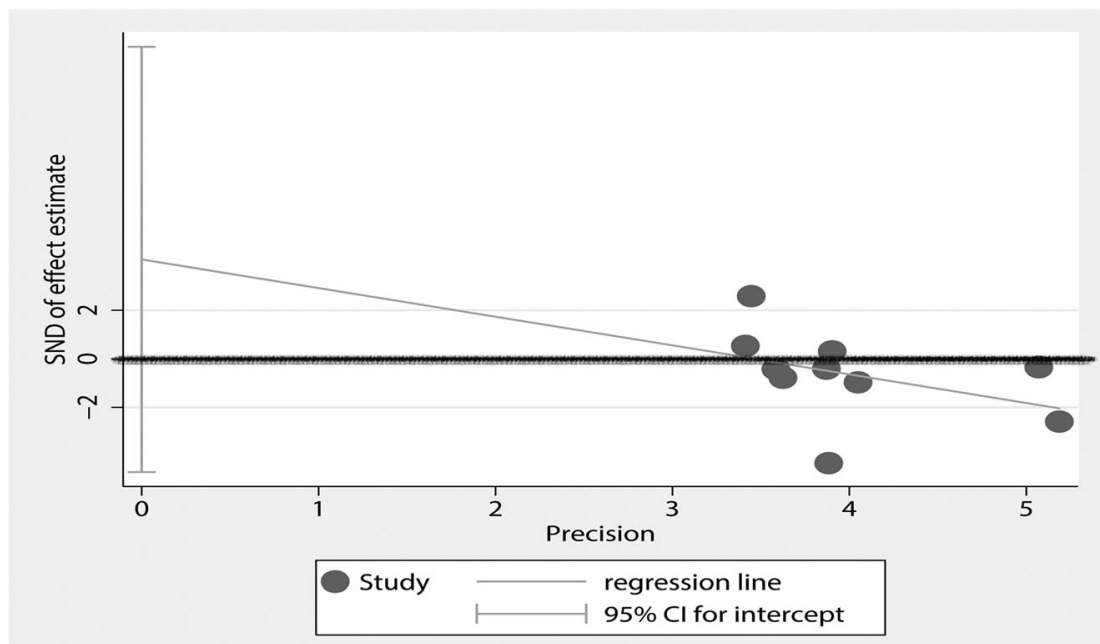

C

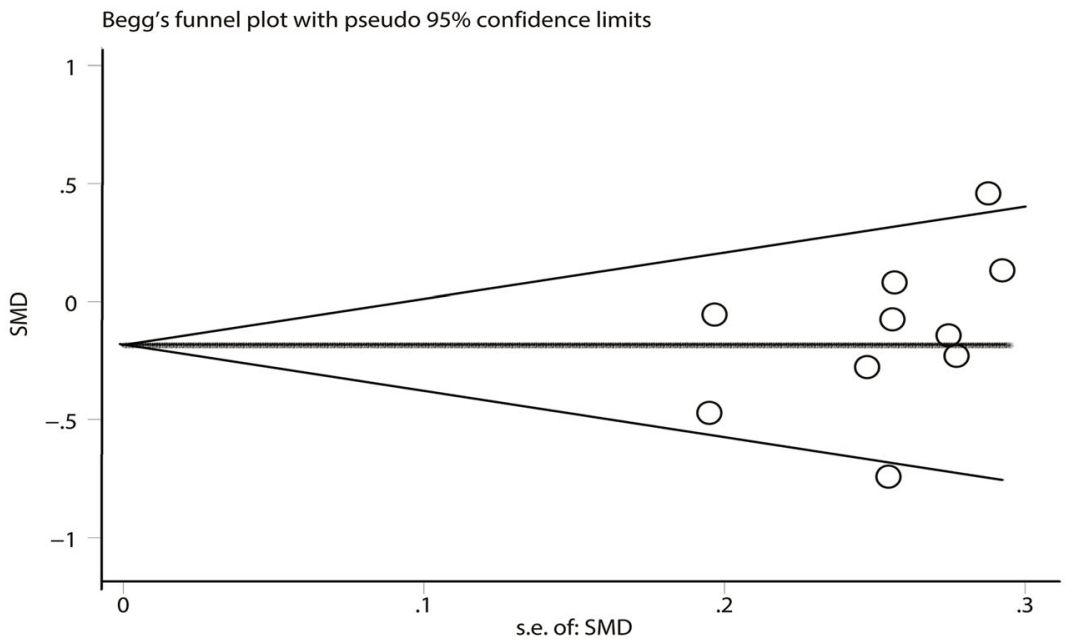

Fig. 6 (See legend on next page.) 
(See figure on previous page.)

Fig. 6 Analysis of sensitivity and publication bias on included studies. a Sensitivity analyses suggested that the exclusion of any study did not substantially alter the estimates and the final statistical performance. $\mathbf{b}$ The Egger's test showed that the discrete graph was basically distributed on both sides of the estimated line. c The funnel plot produced by begg's test showed that the included studies were symmetrically distributed on both sides of the bottom of the funnel plot

studies. We found that for both the vertebrae and femur, the BMD of the valproic acid group was significantly lower than that in the healthy control group, which implies that long-term use of valproic acid decreased the BMD of children with epilepsy. Testing the BMD could help find changes in bone structure in the early stages in children with epilepsy who taken valproic acid, thus providing the clue for early treatment [31]. Long-term use of AEDs may decrease the level of vitamin $\mathrm{D}$, thus reduce the BMD and affect bone structure. Early administration of calcium and vitamin D could prevent bone damage [32].

The 14 studies included in this meta-analysis were case-control studies with good homogeneity [11-23]. A NOS assessment showed that 12 studies had obtained more than seven stars. Publication bias analysis showed that these studies were unlikely to have publication bias. However, these studies have some shortcomings: first, the samples in most studies were relatively small; second, the methods and units of measurement used for bone metabolism indicators differed in these studies, which could lead to methodological heterogeneity; third, the relatively large number of studies from turkey, which may produce geographical bias; fourth, most studies did not focus on the correlation between the plasma concentration of valproic acid and bone metabolism indicators, nor did they compare the correlation between different medication time and bone metabolism indicators.

\section{Conclusion}

The long-term use of valproic acid has no significant effect on serum calcium, phosphorus, ALP, PTH, and osteocalcin in children with epilepsy, but it can cause a decrease of 25-OH-VitD and BMD, suggesting that children with epilepsy who had taken valproic acid for a long time have a risk of osteopenia, but multiple centers and large sample data are still needed to look for specific indicators of early bone damage.

\section{Abbreviations \\ 25-OH-VitD: 25-hydroxy-vitamin D; AEDs: Antiepileptic drugs; ALP: Alkaline phosphatase; BMD : Bone mineral density; Cl: Confidence interval; CYP450: Cytochrome P450; DEXA: Dual-energy x-ray absorptiometry; $\mathrm{M} \pm$ SD: Mean \pm standard deviation; NOS: Newcastle-Ottawa Scale; \\ PTH: Parathyroid hormone; SMD: Standardized mean difference}

\section{Acknowledgements}

We appreciate the great help of Mr. Zhenqi and Miss Yanyizi as reviewers.

\section{Authors' contributions}

$L M, W C Y$ and R BX participated in the design and coordination of the study, carried out the critical appraisal of studies, statistical analysis of studies and wrote the manuscript. All authors have read and approved the manuscript, and ensure that this is the case.

\section{Funding}

None.

\section{Availability of data and materials}

The datasets supporting the conclusions of this article are included within the article.

Ethics approval and consent to participate

Ethical approval is not required for this review.

Consent for publication

Not applicable.

\section{Competing interests}

The authors declare that they have no competing interests.

\section{Author details}

${ }^{1}$ Nursing department, Binhe new district branch, Shenmu Hospital, Shenmu, Yulin City, Shaanxi, China. ${ }^{2}$ Department of Respiratory Medicine, Shenmu Hospital, Shenmu, Yulin City, Shaanxi, China. ${ }^{3}$ Department of Medicine, First Affiliated Hospital, Xi'an Medical University, Xi'an, China.

Received: 20 April 2019 Accepted: 17 February 2020

Published online: 02 March 2020

\section{References}

1. Megiddo I, Colson A, Chisholm D, Dua T, Nandi A, Laxminarayan R. Health and economic benefits of public financing of epilepsy treatment in India: an agent-based simulation model. Epilepsia. 2016;57(3):464-74.

2. Lin Lin Lee V, Kar Meng Choo B, Chung YS, Kundap UP, Kumari Y, Shaikh MF. Treatment, Therapy and Management of Metabolic Epilepsy: A Systematic Review. Int J Mol Sci. 2018;19(3):871..

3. Vidaurre J, Gedela S, Yarosz S. Antiepileptic drugs and liver disease. Pediatr Neurol. 2017;77:23-36.

4. Chateauvieux S, Morceau F, Dicato M, Diederich M. Molecular and therapeutic potential and toxicity of valproic acid. J Biomed Biotechnol. 2010;2010:479364.

5. Sheth RD. Bone health in pediatric epilepsy. Epilepsy Behav. 2004;5(Suppl 2): S30-5.

6. Fan HC, Lee HS, Chang KP, Lee YY, Lai HC, Hung PL, Lee HF, Chi CS. The Impact of Anti-Epileptic Drugs on Growth and Bone Metabolism. Int J Mol Sci. 2016;17(8):1242.

7. Hasaneen B, Elsayed RM, Salem N, Elsharkawy A, Tharwat N, Fathy K, ElHawary A, Aboelenin HM. Bone mineral status in children with epilepsy: biochemical and radiologic markers. J Pediatr Neurosci. 2017;12(2):138-43.

8. Liberati A, Altman DG, Tetzlaff J, Mulrow C, Gotzsche PC, loannidis JP, Clarke M, Devereaux PJ, Kleijnen J, Moher D. The PRISMA statement for reporting systematic reviews and meta-analyses of studies that evaluate health care interventions: explanation and elaboration. J Clin Epidemiol. 2009;62(10):e134.

9. Margulis AV, Pladevall M, Riera-Guardia N, Varas-Lorenzo C, Hazell L, Berkman ND, Viswanathan M, Perez-Gutthann S. Quality assessment of observational studies in a drug-safety systematic review, comparison of two tools: the Newcastle-Ottawa scale and the RTI item bank. Clin Epidemiol. 2014;6:359-68.

10. Biaoxue R, Hua L, Wenlong G, Shuanying Y. Overexpression of stathmin promotes metastasis and growth of malignant solid tumors: a systemic review and meta-analysis. Oncotarget. 2016;7(48):78994-9007. 
11. Akin R, Okutan V, Sarici U, Altunbas A, Gokcay E. Evaluation of bone mineral density in children receiving antiepileptic drugs. Pediatr Neurol. 1998;19(2): 129-31

12. Aksoy A, Sonmez FM, Deger O, Hosver I, Karaguzel G. The effects of antiepileptic drugs on the relationships between leptin levels and bone turnover in prepubertal children with epilepsy. J Pediatr Endocrinol Metab. 2011;24(9-10):703-8.

13. Babayigit A, Dirik E, Bober E, Cakmakci H. Adverse effects of antiepileptic drugs on bone mineral density. Pediatr Neurol. 2006;35(3):177-81.

14. Erbayat Altay E, Serdaroglu A, Tumer L, Gucuyener K, Hasanoglu A. Evaluation of bone mineral metabolism in children receiving carbamazepine and valproic acid. J Pediatr Endocrinol Metab. 2000;13(7):933-9.

15. Caksen H, Dulger H, Cesur Y, Odabas D, Tuncer O, Atas B. No effect of longterm valproate therapy on thyroid and parathyroid functions in children. Int J Neurosci. 2002:112(11):1371-4.

16. Ecevit C, Aydogan A, Kavakli T, Altinoz S. Effect of carbamazepine and valproate on bone mineral density. Pediatr Neurol. 2004;31(4):279-82.

17. Kafali $G$, Erselcan $T$, Tanzer F. Effect of antiepileptic drugs on bone mineral density in children between ages 6 and 12 years. Clin Pediatr (Phila). 1999; 38(2):93-8.

18. Kumandas S, Koklu E, Gumus H, Koklu S, Kurtoglu S, Karakukcu M, Keskin M. Effect of carbamezapine and valproic acid on bone mineral density, IGF-I and IGFBP-3. J Pediatr Endocrinol Metab. 2006;19(4):529-34

19. Oner N, Kaya M, Karasalihoglu S, Karaca H, Celtik C, Tutunculer F. Bone mineral metabolism changes in epileptic children receiving valproic acid. J Paediatr Child Health. 2004:40(8):470-3.

20. Yaghini O, Tonekaboni SH, Amir Shahkarami SM, Ahmad Abadi F, Shariat F, Abdollah Gorji F. Bone mineral density in ambulatory children with epilepsy. Indian J Pediatr. 2015;82(3):225-9.

21. Rauchenzauner M, Griesmacher A, Tatarczyk T, Haberlandt E, Strasak A, Zimmerhackl LB, Falkensammer G, Luef G, Hogler W. Chronic antiepileptic monotherapy, bone metabolism, and body composition in noninstitutionalized children. Dev Med Child Neurol. 2010;52(3):283-8.

22. Serin HM, Koc ZP, Temelli B, Esen I. The bone mineral content alterations in pediatric patients medicated with levetiracetam, valproic acid, and carbamazepine. Epilepsy Behav. 2015;51:221-4.

23. Voudris K, Moustaki M, Zeis PM, Dimou S, Vagiakou E, Tsagris B, Skardoutsou A. Alkaline phosphatase and its isoenzyme activity for the evaluation of bone metabolism in children receiving anticonvulsant monotherapy. Seizure. 2002;11(6):377-80.

24. Ardeshirpour L, Cole DE, Carpenter TO. Evaluation of bone and mineral disorders. Pediatr Endocrinol Rev. 2007;5(Suppl 1):584-98.

25. Zemel BS. Influence of complex childhood diseases on variation in growth and skeletal development. Am J Hum Biol. 2017;29(2). https://doi.org/10. 1002/ajhb.22985

26. Brandi L. 1alpha(OH)D3 one-alpha-hydroxy-cholecalciferol--an active vitamin $D$ analog. Clinical studies on prophylaxis and treatment of secondary hyperparathyroidism in uremic patients on chronic dialysis. Dan Med Bull. 2008;55(4):186-210.

27. Fiscaletti M, Stewart P, Munns CF. The importance of vitamin D in maternal and child health: a global perspective. Public Health Rev. 2017;38:19.

28. Ferin M, Morrell M, Xiao E, Kochan L, Qian F, Wright T, Sauer M. Endocrine and metabolic responses to long-term monotherapy with the antiepileptic drug valproate in the normally cycling rhesus monkey. J Clin Endocrinol Metab. 2003;88(6):2908-15.

29. Guo HL, Jing X, Sun JY, Hu YH, Xu ZJ, Ni MM, Chen F, Lu XP, Qiu JC, Wang T. Valproic acid and the liver injury in patients with epilepsy: an update. Curr Pharm Des. 2019;25(3):343-51.

30. Fewtrell MS. Bone densitometry in children assessed by dual $x$ ray absorptiometry: uses and pitfalls. Arch Dis Child. 2003;88(9):795-8.

31. Vera V, Moran JM, Barros P, Canal-Macias ML, Guerrero-Bonmatty R, CostaFernandez C, Lavado-Garcia JM, Roncero-Martin R, Pedrera-Zamorano JD. Greater calcium intake is associated with better bone health measured by quantitative ultrasound of the phalanges in pediatric patients treated with anticonvulsant drugs. Nutrients. 2015;7(12):9908-17.

32. Vestergaard P. Effects of antiepileptic drugs on bone health and growth potential in children with epilepsy. Paediatr Drugs. 2015;17(2):141-50.

\section{Publisher's Note}

Springer Nature remains neutral with regard to jurisdictional claims in published maps and institutional affiliations.

Ready to submit your research? Choose BMC and benefit from:

- fast, convenient online submission

- thorough peer review by experienced researchers in your field

- rapid publication on acceptance

- support for research data, including large and complex data types

- gold Open Access which fosters wider collaboration and increased citations

- maximum visibility for your research: over $100 \mathrm{M}$ website views per year

At BMC, research is always in progress.

Learn more biomedcentral.com/submissions 